BORIS NOSOW

Instytut Słowianoznawstwa

Rosyjskiej Akademii Nauk, Moskwa

\title{
PAŃSTWO (JEGO POWSTANIE, UPADEK I ODRODZENIE) JAKO HISTORYCZNIE UWARUNKOWANA FORMA SPOŁECZNO-POLITYCZNEJ ORGANIZACJI SPOŁECZEŃSTWA
}

1. Jak upadaja państwa i jak na nowo powstają? Czy jest możliwa w historiografii jakaś uogólniająca refleksja na ten temat? Co maja na ten temat do powiedzenia historykowi inne nauki humanistyczne i społeczne (koncepcja "failed state" $w$ teorii politycznej)?

Zagadnienie upadku i odrodzenia się państw tylko w niewielkim stopniu może być rozpatrywane w kategoriach uniwersalnych. Za przykład negatywny w tym względzie może posłużyć antyhistoryzm Karla Poppera i jego uczniów w dziedzinie politologii, którzy sprowadzali proces historyczny do rywalizacji społeczeństw „otwartego" i „zamkniętego”, nie dając przecież klarownego opisu „społeczeństwa otwartego” jako takiego.

Dla historyka pozostaje oczywiste, że problematyka upadku i odrodzenia się państw może być rozpatrywana wyłącznie w kontekście dziejowym, a więc jako część składowa konkretnego procesu historycznego. Dla jej analizy podstawowe znaczenie ma zrozumienie historycznych uwarunkowań genezy państwowości, uwarunkowań dziejowych ewolucji jej form i typów, a przede wszystkim koncepcja charakteru państwa $\mathrm{w}$ wymiarze społecznym i jego funkcji. To ostatnie zagadnienie w ciągu co najmniej trzech ostatnich stuleci, zatem od epoki oświecenia, jest przedmiotem intensywnej dyskusji wśród historyków, prawoznawców i socjologów. Naturalnie, dyskusje w ramach poszczególnych dziedzin oraz ich osiągnięcia badawcze bez wątpienia sprzyjają ich wzajemnemu wzbogaceniu. 
Proces historyczny daje nam praktycznie nieograniczoną liczbę przykładów pojawienia się i upadku państw. Przyczynami tych zjawisk były na przykład względy przyrodnicze i klimatyczne, by przywołać choćby koncentrację ludności w Mezopotamii lub w dolinie Nilu, warunkującą powstanie państw starożytnego Wschodu. Innym razem w następstwie naturalnych katastrof upadały cywilizacje, co, prawdopodobnie, miało miejsce w przypadku państwowości kultury kreteńsko-mykeńskiej. Przyczyny upadku państw związane z wielkimi katastrofami nie są wykluczone i w naszych czasach, na przykład jako efekt możliwych klęsk ekologicznych i technogennych, nie mówiąc już o następstwach zastosowania broni jądrowej.

Mówiąc o upadku i odrodzeniu się państw, należy pamiętać, że omawiany tu proces historyczny może być rozpatrywany z dwóch punktów widzenia. Po pierwsze, jako naturalny (uwarunkowany obiektywnie) proces zamiany socjalnych i politycznych form organizacji społecznej lub, po drugie, jako sformalizowane przejście od jednej państwowej i prawnej organizacji instytucji władzy publicznej do innej. Jako ilustrację można by przywołać niemało przykładów. Przechodząc do szczegółów, zadajmy pytanie, czy można uważać za upadek i odrodzenie państwowości na Wyspach Brytyjskich ustanowienie władzy Wilhelma Zdobywcy w Anglii po bitwie pod Hastings. Na tym samym poziomie rozważmy, w jaki sposób scharakteryzować los państwowości chińskiej, który wyznaczyła mongolska oraz mandżurska ekspansja. Wreszcie należy wspomnieć na absolutnie niejednoznaczne interpretowanie przez współczesną publicystykę dziejów państwowości rosyjskiej i wielu innych państw Europy Środkowo-Wschodniej w XX w. Odnośnie do ostatniego przykładu należy odwołać się do pytań 3-5 niniejszej ankiety.

Chociażby w oparciu o przywołane tu przykłady, można zauważyć, że podejście formalno-prawne do określenia samego zjawiska upadku, zagłady i odrodzenia się państw - przy całej wadze jego zastosowania w realizacji konkretnych zadań badawczych - w niewielkim stopniu umożliwi wypracowanie przekonywającej i akceptowalnej z naukowego punktu widzenia koncepcji. W konsekwencji poszukiwania naukowe korzystniej byłoby skierować ku badaniom zmian form socjalnych i politycznych organizacji społecznej. Jest powszechnie wiadome, że aktualność i waga owej problematyki zaowocowała w literaturze politycznej bogactwem prac i koncepcji począwszy od teologicznych oraz innych apologetycznych spojrzeń na państwo, aż do ideologii anarchizmu. Jeżeli będziemy abstrahować od wszelkiego rodzaju antyhistorycznych wyobrażeń, to w ramach nauki kwestię natury i istoty władzy państwowej można sprowadzić do dwóch koncepcji: pierwsza traktuje państwo 
jako wyraziciela interesu powszechnego (jak zostało to opisane $\mathrm{w}$ filozofii Georga Hegla), druga zaś widzi w nim „aparat przymusu”, regulujący stosunki społeczne w interesie warstwy panującej; została ona zaprezentowana przez Karola Marksa i jego następców. W ramach tych dwóch swoistego rodzaju biegunów rozwija się dyskurs w historiografii nad poruszoną tu problematyką. Zastrzeżmy przy tym, że pierwsza koncepcja (heglowska) zdecydowanie dominuje, nawet przy istotnych wątpliwościach, które w najnowszej historiografii łączą się z niejednoznaczną oceną funkcji tzw. elit politycznych.

Istotne znaczenie dla zrozumienia procesów upadku i odrodzenia się państw posiadają wyobrażenia o formach państw i władzy państwowej oraz ich przemianach w procesie historycznego rozwoju, w tym także o ewolucyjnym i rewolucyjnym sposobie ich przekształceń. Mówiąc o formie państwa, nie poruszamy tu kwestii często stosowanych terminów politologicznych, które określają cechy typologiczne, takich jak demokracja, autokratyzm, oligarchia, totalitaryzm itp.

Zgodnie z kolejnością chronologiczną można warunkowo wyodrębnić formy protopaństwowe, znane w starożytności z podań i ze źródeł pochodzenia zewnętrznego, dane o tych bytach czasami uzyskują dodatkowe potwierdzenie w odkryciach archeologicznych. Takie państwa prawdopodobnie także przeżywały okresy kształtowania się, rozkwitu, upadku i odrodzenia. Wszelako oczywiste pozostaje, że posiadane przesłanki nie dają wystarczających podstaw do włączenia ich zarówno w szereg ogólnych prawidłowości, jak i identyfikacji ogólnych cech charakterystycznych dla tej grupy.

W świecie starożytnym funkcjonowały dwie podstawowe formy państwowości: wschodni despotyzm i greckie miasta-państwa (poleis), które w epokach hellenistycznej i Imperium Rzymskiego dały początek państwom i prowincjom państwowym, w których obie te formy przejawily się w najdziwaczniejszych kombinacjach. Jednocześnie zjawiska upadku i odrodzenia się państw w tamtej epoce dały liczne i różnorodne przykłady, zarówno z punktu widzenia konwergencji systemów społecznych, jak i wpływu zewnętrznych (międzynarodowych) czynników. Wszelako te ostatnie odegrały w tych procesach rolę decydującą. Najbardziej wyraźnym i charakterystycznym przykładem w tym względzie stał się upadek Imperium Rzymskiego spowodowany presją ze strony barbarzyńców.

We wczesnym średniowieczu najważniejszymi formami państwowości były królestwa barbarzyńskie, spośród których wydatną rolę odgrywały średniowieczne „imperia”: Imperium Karola Wielkiego, Cesarstwo Ottonów w Niemczech, Polska pierwszych Piastów, Ruś Kijowska (monarchia Rurykowiczów). Ich rozdrobnienie feudalne na poszczególne faktycznie 
niezależne ziemie - państwa, nawet przy zachowaniu formalnej senioralnej hierarchii i nierzadko mający miejsce podział tych tworów między potomków władających nimi monarchów, dokonany w ramach panującej dynastii, w najmniejszym stopniu nie wiąże się z upadkiem i rozbiciem w tym rozumieniu, w jakim spotykamy je w epokach wcześniejszych i późniejszych. Rozwój gospodarki, struktury społecznej i kultury w epoce dojrzałego średniowiecza doprowadził królestwa barbarzyńskie do decentralizacji, do wykształcenia się lokalnych ośrodków, gospodarczych, politycznych i kulturalnych, a także w efekcie do powstania mniejszych państw i ukształtowania się, mówiąc słowami Nikołaja Kariejewa (Nikolaj Kareev), państw terytorialnych (поместье-государство), dysponujących wojskowymi (w ramach zależności wasalnej), sądowymi, fiskalnymi i innymi uznanymi atrybutami odrębności. Czy można zatem rozpatrywać proces rozdrobnienia feudalnego w kategoriach procesu upadku państw i w konsekwencji - polityczną centralizację wczesnej epoki nowożytnej jako ich odrodzenie? Wydaje się nam, że opisany wyżej proces w niewielkim tylko stopniu może zostać opisany we wspomnianym paradygmacie.

2. Czy rozbiory Rzeczypospolitej sa wydarzeniem bez precedensu? A dokładniej: jakie elementy procesu upadku Rzeczypospolitej można uznać za typowe, a jakie za wyjątkowe w perspektywie porównawczej? Z samej historii Rzeczypospolitej wspomnieć przecież można jej głęboki kryzys w 1655 r. w czasie potopu szwedzkiego (nawiazanie unii litewsko-szwedzkiej). Z innych regionów przypomnieć można o planach rozbioru monarchii habsburskiej w czasie wojen ślaskich $i$ wojny siedmioletniej, o stopniowej absorpcji Hetmanatu przez Rosję w czasach między Piotrem I a Katarzyna czy też o podwójnym rozpadzie Królestwa Węgierskiego (po roku 1526 i ponownie po 1918). Czy porównania tych wszystkich (a także z pewnościa wielu innych) wydarzeń historycznych rzucaja jakieś światło na problem rozbiorów?

We wczesnej epoce nowożytnej podstawową formą państwowości stały się „państwa scentralizowane”. W charakterze synonimów tego terminu stosuje się także pojęcia „państw narodowych” lub „współczesnych państw" (ostatni termin w zaprezentowanym tu znaczeniu był używany przez Heinza Schillinga). Cechą powszechną państw scentralizowanych było ześrodkowanie życia gospodarczego i społecznego na bazie narodowych więzi handlowych (w Europie Zachodniej) lub centralizacji własności ziemskiej i wewnętrznej konsolidacji stanów panujących, a także ustanowienia pańszczyźnianej zależności chłopów (w Europie Środkowej i Wschodniej na wschód od Łaby). Podstawowymi formami państwowymi 
centralizacji były monarchia i republika, przy czym występowały w ich ramach instytucje przedstawicielstwa stanowego w różnorakiej formie. Przy tym miały miejsce rozliczne połączenia monarchicznej i republikańskiej formy władzy państwowej. Formalną cechą państw scentralizowanych było istnienie wewnętrznej i zewnętrznej suwerenności, co znalazło potwierdzenie $\mathrm{w}$ prawie międzynarodowym, choćby w ramach systemu westfalskiego. $\mathrm{Z}$ tego punktu widzenia funkcjonowanie stanowej organizacji Kozactwa na Ukrainie w wiekach od XVI do XVIII, na czele której stali hetmani, będący stanowymi przedstawicielami, nie daje podstaw, aby opisać ją w kategoriach państwa w takim samym stopniu, jak istnienie stanowych i prowincjonalnych przywilejów Prus Królewskich w znikomym tylko stopniu daje możliwość zaliczania tej prowincji Rzeczypospolitej do państw, pomimo że proces włączenia województw pomorskiego, malborskiego i chełmińskiego oraz Księstwa Warmińskiego w skład państwa polskiego posiada swoją niezwykle złożoną historię. Z tego punktu widzenia specjalnej analizy wymaga historia i status państwowy Świętego Cesarstwa Rzymskiego Narodu Niemieckiego.

Epoka wczesnej nowożytności była czasem aktywnej ekspansji terytorialnej wielkich mocarstw i koalicji, na czele których one stały, albowiem ekspansja terytorialna, kontrola nad szlakami handlowymi i wiążące się z tym powiększenie potencjału fiskalnego ludności tworzyły realną bazę politycznej i wojskowej potęgi państw. W tych warunkach wojny europejskie, różnorakie formy terytorialnych zaborów stawały się naturalnym sposobem ewolucji stosunków międzynarodowych, co pod względem ideologicznym i prawnomiędzynarodowym znalazło finał w koncepcji „europejskiej równowagi sił”, jak to rozpatrywał Karl von Aretin.

Jednakże rozbiory Rzeczypospolitej w XVIII w. wśród wszelkiej maści terytorialnych zaborów/,rozbiorów” (np. szwedzkich posiadłości w ramach systemu ustanowionego pokojem w Nystad w 1721 r.), sądzę, stanowią zjawisko unikatowe. Po pierwsze, były następstwem nieposiadającego analogii protektoratu wielkich mocarstw nad szlachecką republiką, który został ustanowiony już w trakcie wielkiej wojny północnej, poczynając od lat 1716-1717, i został sformalizowany po jej zakończeniu. Po drugie, decydującym czynnikiem rozbiorów państwa polsko-litewskiego stały się kryzysy międzynarodowe, które rodziły się poza jego granicami - w kwestii wschodniej (losów Porty Otomańskiej) i w efekcie potrzeby zjednoczenia absolutystycznych monarchii ancien regime'u w walce przeciwko rewolucji francuskiej. Po trzecie, z prawnomiędzynarodowego punktu widzenia polityka rozbiorów Polski była realizowana drogą dyplomatyczną bez starcia zbrojnego między mocarstwami inicjującymi rozbiory. Po czwarte, wina za upadek Rzeczypospolitej była 
przerzucona przez mocarstwa zaborcze na samą republikę, a ta ostatnia została przymuszona do uznania de iure dwóch pierwszych rozbiorów. Wiele innych przyczyn, które zostały szczegółowo przeanalizowane $\mathrm{w}$ historiografii, odegrało także swoją rolę. W pewnym stopniu jakieś analogie z rozbiorami Polski w XVIII w. można dostrzec w postanowieniach kongresu wiedeńskiego w 1815 r. w kwestiach niemieckiej i polskiej, jednakże twardo utrzymujemy pogląd, że chociaż wielkie mocarstwa nie raz w następnych latach zmieniały kształt polskich granic, to nie ma żadnych podstaw, aby rozpatrywać te wydarzenia jako „rozbiory Polski", a tym bardziej, aby dostrzegać w nich kontynuację tej polityki, która była realizowana w stosunku do Rzeczypospolitej w XVIII w. Przy tym teza o unikatowości rozbiorów Polski w XVIII w. nie oznacza rezygnacji z komparatystyki historycznej w tym obszarze badań, jeżeli rozumieć to jako zgłębianie historii Polski XVIII w. w szerokim kontekście międzynarodowym.

3. Budowa czy odbudowa? Jaka była rola tradycji historycznej dla państw, powstajacych na gruzach imperiów w roku 1918? Czy (i w jakich wypadkach) mamy do czynienia z ciagle żywymi pozostałościami (mentalnymi, ustrojowymi, gospodarczymi czy innymi) historycznej państwowości, które w istotny sposób wspóttworza kształt nowego państwa? Czy może częściej napotykamy tylko pewna tradycje, która buduje ideologię legitymizacyjna, lecz nie wpływa na konkretne rozwiązania ustrojowe nowego tworu państwowego? Innymi słowy, $i$ ograniczając się do przypadku polskiego, w jakim stopniu właściwym kontekstem pozwalajacym zrozumieć rozwiazania ustrojowe i praktykę polityczna II Rzeczypospolitej Polskiej jest polska historia, w jakim zaś - konkretna sytuacja roku 1918 i porównawcza perspektywa uwzględniająca tworzace się wówczas państwa?

Mówiąc o odrodzeniu państwa polskiego, należy przyjąć, że jego warunkiem i przesłanką stał się kryzys międzynarodowy, następstwem i wynikiem którego była I wojna światowa, rewolucja w Rosji i wydarzenia rewolucyjne w innych krajach europejskich w latach 1917-1920, albowiem dopiero w 1921 r. uległy określeniu i stabilizacji ustój wewnętrzny, granice państwowe i pozycja międzynarodowa II Rzeczypospolitej. Tematyka przywołanego tu kryzysu i jego następstw dla Polski jest na tyle obszerna, że bezcelowe jest dotykanie jej w ramach ograniczonej objętościowo odpowiedzi na pytanie zadane w ankiecie. Pragniemy tylko przywołać słowa Jerzego Michalskiego, że kryzysy międzynarodowe były niezbędnym warunkiem do oswobodzenia Polski od zagranicznej zależności, jednocześnie stanowiąc najważniejsze zagrożenie dla jej bytu. 
Kwestia tradycji historycznych w dziedzinie odrodzenia państwa i procesów państwotwórczych wydaje się dość scholastyczna, ponieważ w historii politycznej możemy odnaleźć niemało przykładów dążeń kręgów rządzących różnorakich państw (w szczególności nowo powstałych) zmierzających do „ustarodawnienia” swojej historii poprzez powoływanie się na odrodzenie swej państwowości, która funkcjonowała w przeszłości. Bez wątpienia przywołany tutaj przypadek nie dotyczy odrodzonej w 1918 r. państwowości polskiej. Można to udowodnić nieprzerwanymi procesami rozwoju kultury polskiej oraz ciągłością przejawów polskiego ruchu narodowowyzwoleńczego. I wreszcie najistotniejsze: w efekcie odrodzenia państwowości polskiej zwycięstwo odniosły te siły społeczne, które były wyrazicielami tej państwowości w epoce upadku Polski, które w czasach zaborów, przeszedłszy istotną transformację, zachowały swój status społeczny i potrafiły w toku wojny 1920 r. z Rosją Radziecką obronić państwo, nie dopuszczając do przekształcenia Polski w przyczółek światowej rewolucji socjalistycznej, wedle doktryny bolszewików. Uwarunkowania społeczne narodowego państwa polskiego, w ostatecznym rozrachunku, określiły konwergencję tradycji i nowatorstwa w jego politycznym, prawnym i ideowym ukształtowaniu się w trakcie procesów państwotwórczych.

4. Druga strona tej samej monety: (od)budowa państw to $w$ wielu wypadkach jednocześnie rozpad imperiów albo innych państw, uprzednio panujących na danym terytorium. Spróbujmy więc spojrzeć od strony imperialnego centrum. Jakie sa możliwości polityki centrum wobec irredenty na prowincjach: co zwiększa/zmniejsza możliwości jej sukcesu? Czy sa jakieś prawidłowości przyjmowania polityki represji badź ustępstw wobec dążeń odśrodkowych?

Odpowiadając na tak postawione pytanie, zmuszony jestem zastrzec, że nie mogę analizować terminu „imperium” jako jakiegoś generalizującego pojęcia naukowego, ponieważ jego treść wydaje się nieokreślona i może być rozumiana bardzo subiektywnie. Wiadomo, że we współczesnej publicystyce i politologii (a z politologii termin ten nierzadko zapożyczany jest przez historyków) pojęcie „imperium” nie sprowadza się do formalnego prawnopaństwowego i prawnomiędzynarodowego statusu jakiegokolwiek państwa. W większości przypadków chodzi o potężne z militarnego punktu widzenia państwa z autorytarną formą władzy (co bynajmniej nie musi być sprzeczne $\mathrm{z}$ ich republikańskim lub monarchiczno-konstytucyjnym ustrojem); o państwa wielonarodowe; o państwa, które osiągnęły istotne rozszerzenie terytorialne drogą podboju zbrojnego czy też ekspansji ekonomicznej lub kulturowej; wreszcie o państwa, w których 
politycznie i ideologicznie znaczącą rolę odgrywał militaryzm i wielkomocarstwowy szowinizm. Nawet jeżeli ograniczymy się do epoki XIX w., to do pojęcia „imperium” możemy włączyć wszystkie bez wyjątku wielkie mocarstwa, w tej liczbie Imperium Osmańskie, USA, Japonię i Chiny. Przy tym nie ulega wątpliwości, że ani historycznie, ani typologicznie według tożsamości istniejących cech i atrybutów, nawet Austro-Węgry, Niemcy i Rosja nie stanowiły umownie odrębnej grupy, pomijając cesarskie tytuły monarchów zasiadających tam na tronach. Jeżeli wyjdziemy poza granice XIX w., to pojęcie ,imperium” w ogóle traci wszelką treść, pomimo historycznie utrwalonych prawem kaduka nazw własnych, np. Imperium Aleksandra Macedońskiego, Juliusza Cezara, Czyngis-chana.

Kryzys wielkich mocarstw w efekcie I wojny światowej w każdym kraju przyniósł odrębne objawy. Umownie państwa te można podzielić na trzy grupy: do pierwszej należy Rosja, w której doszło do proletariackiej rewolucji i rozgorzała wojna domowa; do drugiej należy zaszeregować państwa centralne, które także były objęte procesami rewolucyjnymi i zostały upokorzone imperialistycznym pokojem wersalskim. Dyktat zwycięzców, który głosił, zgodnie z punktami Thomasa Woodrowa Wilsona, regulacje według zasad narodowych, doprowadził do kardynalnych zmian na mapie Europy Środkowej i Wschodniej. Narodowe dążenia ludów zostały wykorzystane przez państwa Ententy do przebudowy świata, jednakże nie doprowadziło to do sprawiedliwego uregulowania granic. Do trzeciej grupy należały europejskie państwa Ententy, których siły zostały w znacznym stopniu nadszarpnięte przez wojnę, a w obszarze ich polityki wewnętrznej nieustannie wzmacniały się, powstałe już w latach wojny, tendencje zespolenia się potężnego finansowego i przemysłowego kapitału z aparatem państwowym. Wszelako, bez względu na odniesione zwycięstwo, zarówno Wielka Brytania, jak i Francja, w efekcie wojny i po jej zakończeniu musiały się zmierzyć ze wzrostem dążeń narodowowyzwoleńczych w koloniach i w konsekwencji z erozją własnej imperialnej, kolonialnej struktury. Do trzeciej grupy należy zaliczyć także Stany Zjednoczone, które tylko w niewielkim stopniu były zaangażowane $\mathrm{w}$ wojnę, natomiast $\mathrm{w}$ stopniu maksymalnym potrafiły wykorzystać owoce zwycięstwa. Wszelako i dla Ameryki okazało się niemożliwe odtworzenie wcześniejszych form stosunków międzynarodowych, opartych na niepodzielnym panowaniu wielkich mocarstw, charakterystycznym dla przełomu XIX i XX w.

Uwzględniając te zjawiska, można przejść do kwestii stosunków wzajemnych między metropolią a narodowo odrębnymi kresami i koloniami. Historycznie takie stosunki po I wojnie światowej wydają się bardzo zróżnicowane. Jednakże ogólnie możliwość osiągnięcia kompromisu między 
metropolią a kolonią (skolonizowanymi kresami) zależała od gotowości warstw społecznie i gospodarczo panujących obydwu stron do zawarcia porozumienia, które chroniłoby wspólnymi siłami ich własną dominującą pozycję w życiu gospodarczym i społecznym. W tym schemacie zachowanie rosyjskiej władzy nad Królestwem Polskim w XIX w. w decydującym stopniu zależało od sojuszu, używając określenia Stefana Kieniewicza, „klas posiadających” Polski (szlachty, ziemian i polskiej burżuazji) z władzami carskimi, co gwarantowało zachowanie ich dominującej pozycji w polskim społeczeństwie. Konflikty władz carskich z polskimi „klasami posiadajaccymi" w kwestii ustroju konstytucyjnego w latach dwudziestych XIX w. i w sprawie uwłaszczenia chłopów w latach 1859-1861, mimo że doprowadziły do polskich powstań, nie zachwiały pozycji imperium carów w Polsce, przeciwnie, wspomniany sojusz umożliwił nawet władzom carskim postawienie w szeregu celów Rosji w I wojnie światowej włączenia całości ziem polskich w skład imperium, na prawach obiecanej lecz bliżej nieokreślonej autonomii. Kompromisu tego rodzaju polskie „klasy posiadające” nie spodziewały się po Rosji Radzieckiej, zatem nie miały innych możliwości, jak tylko wykorzystać międzynarodowy wojenny kryzys 1918 r., aby z całym zdecydowaniem walczyć o odbudowę państwa polskiego, w sojuszu z państwami centralnymi lub po stronie zwycięskiej Ententy.

5. Nowe państwa powstajace w wyniku rozpadu imperiów po I wojnie światowej $w$ większości (choć nie wyłącznie i nie bezwarunkowo) przyjmowały koncepcję państwa narodowego. Jaki jest zwiazek tej idei z odbudowa upadtych państw? Czy można zaryzykować uogólnienie, że wzrost znaczenia idei narodowej w ciagu wieku XIX nadaje procesom tworzenia badź odtwarzania państw nowy charakter, odmienny od dawniejszych epok, czy też podobieństwa międzyepokowe sa ważniejsze niż różnice?

Sama przez się koncepcja państwa narodowego posiada w dość dużym stopniu charakter abstrakcyjny, albowiem z punktu widzenia historycznego, wedle własnej definicji tego pojęcia, państwa narodowe nie istnieją. Już od czasów historyków francuskich epoki restauracji w nauce zadomowił się pogląd, że państwo, jego instytucje i metody (technologie) władzy są funkcją stosunków społecznych. Koncepcja ta rozwinęła się w filozofii Hegla, młodoheglistów i wczesnego Marksa. Dowolne społeczeństwo, a państwo wyobraża sobą całość swych instytucji, jawi się jako wewnętrznie sprzeczna struktura, rozbita według cech społecznych i politycznych. Podziały te stanowią istotę wewnętrznych sprzeczności, które przynoszą impuls i określają kierunek rozwoju społecznego. Wszelako 
panujące warstwy społeczne potrzebują ideologii, która by konserwowała ich status socjalny i w warstwie ideologicznej niwelowała podstawowe wewnętrzne sprzeczności. Rolę taką odgrywa ideologia narodowa i ideologia państwa narodowego.

Moskwa, 22 czerwca $2017 \mathrm{r}$.

Z jęz. rosyjskiego przełożył Tomasz Szwaciński

Biogram: Boris Władimirowicz Nosow, doktor nauk historycznych, kieruje Wydziałem Historii Narodów Słowiańskich Europy Środkowej w Okresie Nowożytnym Instytutu Słowianoznawstwa RAN w Moskwie. Zastępca przewodniczącego rosyjskiej części Komisji historycznej rosyjsko-polskiej RAN i PAN. Specjalizuje się w historii politycznej I Rzeczypospolitej, Rosji i historii stosunków międzynarodowych w Europie XVIII w. - pierwszej połowie XIX w. oraz w rosyjsko-polskich kontaktów naukowych; kontakt: bnossov@mail.ru. 